\title{
PARTISIPASI MASYARAKAT DESA DALAM PENDIDIKAN \\ PESANTREN SEBAGAI UPAYA PENGEMBANGAN \\ MANAJEMEN BUDAYA ISLAMI
}

\author{
Ittihad \\ STIT Palapa Nusantara Lombok NTB \\ email: ittihadkalijaga@gmail.com
}

Penelitian ini bertujuan untuk menganalisis dan mendeskripsikan partisipasi pendidikan pesantren dalam upaya pengembangan manajemen budaya islami di MA Darusshalihin NW melalui manajemen madrasah, budaya madrasah, penerimaan peserta didik baru, kurikulum madrasah, pengembangan sumber daya manusia, dan pengelolaan sarana prasarana pendidikan. Penelitian ini menggunakan kualitatif dengan rancangan studi kasus. Data dalam penelitian diperoleh dari informan penelitian, yaitu kepala, kepala tata urusan, wakil kepala, dewan guru dan siswa. Teknik pengumpulan data yang digunakan adalah wawancara, observasi, dan studi dokumentasi. Hasil penelitian menunjukkan bahwa 1) kepala madrasah telah menerapkan fungsi manajemen : perencanaan, pengorganisasian, pelaksanaan, pengawasan dalam manajemen madrasah, 2) Budaya madrasah berkaitan erat dengan nilai-nilai positif dan norma-norma yang mengikat seluruh santri madrasah, 3) penerimaan siswa baru untuk menjaring siswa kelas regular dan kelas unggulan dilaksanakan untuk mendapatkan input yang baik yang akan menghasilkan output yang amat baik, 4) kurikulum pembelajaran MA Darusshalihin NW Kalijaga menggunakan Kurikulum 2013 dan untuk kurikulum muatan lokal dan kecakapan hidup belum seluruhnya dikembangkan, 5) Sumber daya manusia terutama guru beserta staf di MA Darusshalihin NW Kalijaga sudah berjalan dan terlaksana dengan baik guna pembentukan keterampilan profesional dan perbaikan layanan sekolah, dan 6) pengelolaan sarana dan prasarana pendidikan yang ada di madrasah sudah baik.

Kata kunci: partisipasi masyarakat desa, pengembangan manajemen, manajemen budaya islami 


\section{PENDAHULUAN}

Madrasah Aliyah adalah lembaga pendidikan yang sederajat dengan sekolah menengah atas yang mempunyai ciri islam yang dikelola dan di bawah naungan Kementerian Agama Republik Indonesia. Sebagai lembaga pendidikan yang mempunyai ciri khas islam, madrasah memegang peranan penting dalam proses pembentukan kepribadian anak didik, karena melalui pendidikan madrasah ini para orang tua berharap anak-anaknya memiliki dua kemampuan sekaligus, tidak hanya pengetahuan umum (IPTEK) tetapi juga memiliki kepribadian dan komitmen yang tinggi terhadap agamanya (IMTAQ). Upaya meningkatkan mutu pendidikan, tidak bisa terlepas dari upaya perbaikan manajemen madrasah.

Pendidikan di madrasah saat ini harus diperbaiki, minimal pada aspek perbaikan kurikulum dan perbaikan kualitas pembelajaran, kualitas SDM baik tenaga pendidik maupun tenaga kependidikan, perbaikan sarana prasarana, dan partisipasi masyarakat dalam penyelenggaraan pendidikan. Strategis yang harus dikembangkan oleh madrasah untuk menjadi madrasah yang efektif dalam membangun citra aura yang positif sehingga ada akselerasi peningkatan kualitas madrasah. Madrasah harus mempunyai visi dan misi yang jelas, kepala madrasah yang profesional, guru yang profesional, lingkungan yang kondusif, ramah siswa, manajemen yang kuat, kurikulum yang luas tapi seimbang, penilaian dan pelaporan prestasi siswa yang bermakna, serta pelibatan orang tua/masyarakat. Madrasah Aliyah Darusshalihin NW Kalijaga adalah salah satu lembaga pendidikan di Darusshalihin NW yang berkomitmen terhadap mutu agar mampu menjadi sekolah yang unggul. Visi madrasah adalah menjadi madrasah unggulan, berakhlakul karimah dan berinovasi. Dalam memenuhi visi tersebut madrasah terus mencari sesuatu yang baru yang mampu menjadikan madrasah sebagai lembaga pendidikan pilihan masyarakat di Kalijaga. Kepala madrasah selalu berinovasi dan mengembangkan ide-ide baru baik dalam pola/ metode pembelajaran untuk murid dan juga pola manajemen yang tepat bagi guru dan staf. Karena kualitas suatu lembaga pendidikan tak hanya ditentukan oleh kualitas pembelajaran semata namun juga dipengaruhi bagaimana lembaga pendidikan tersebut mampu mengelola pegawainya dengan baik sehingga memunculkan 
motivasi dan potensi pegawainya untuk mampu mengupayakan yang terbaik dalam melakukan tugasnya.

Madrasah Aliyah Darusshalihin NW Kalijaga menggunakan manajemen mutu terpadu dimana fokusnya adalah perbaikan terus menerus dan kepuasan pelanggan menjadi hal yang utama. Guna mencapai kepuasan pelanggan dan menjadi madrasah unggulan, madrasah memiliki tiga langkah yang strategis antara lain: Pertama, be Inovative, menciptakan suatu produk terobosan yang baru. Inovasi bisa diolah pada materi kurikulumnya, fasilitas, atau pengajarannya. Kedua, be different, bila inovasi sulit dicapai, maka membuat yang berbeda dari sekolah lain juga merupakan jembatan yang tidak rumit. Seperti membuat program kelas unggulan yang berbeda dengan sekolah lain. Ketiga be the best, bila ingin menciptakan produk yang sama setidaknya kita bisa melayani dengan cara yang terbaik, dari fasilitas dan pengajaran yang terbaik. Kepala madrasah memiliki peran penting dalam mengembangkan Sumber Daya Manusia (SDM) madrasah. Pengembangan SDM dapat dilakukan melalui melalui pendidikan dan pelatihan. Kepala madrasah memberikan kesempatan dan memotivasi guru untuk menambah ilmu dan pengalamannya untuk studi lanjut ke jenjang yang lebih tinggi. Hal ini menunjukkan bagaimana guru-guru di madrasah berusaha untuk mengembangkan keilmuan dan keprofesionalan mereka yang berguna untuk peningkatan kualitas mereka dalam pembelajaran dan peningkatan prestasi belajar peserta didik.

Budaya madrasah juga berpengaruh terhadap peningkatan prestasi dan motivasi siswa untuk berprestasi, sikap dan motivasi guru serta produktivitas dan kepuasan kerja guru. Nilai-nilai karakter positif dikembangkan sehingga memiliki kekuatan untuk terus menerus mempengaruhi perilaku seluruh warga madrasah. Guru harus mampu memberikan motivasi dan inspirasi bagi siswa seperti: datang tepat waktu, jujur, dan disiplin dalam melaksanakan tugas merupakan nilai dan teladan yang harus senantiasa dijaga dalam kehidupan sekolah.

Manajemen pendidikan memiliki dasar manajemen yang sama dengan manajemen pada umumnya, hanya lebih ditekankan pada pengelolaan pada 
tingkat pendidikan. memberikan definisi tentang manajemen pendidikan yaitu: "Educational management is a field of study and practice concerned with the operation of educational organization". Dari pengertian ini kita dapat mengetahui bahwa manajemen pendidikan adalah salah satu bidang studi yang berkaitan dengan praktik pengelolaan organisasi pendidikan. Manajemen pendidikan adalah rangkaian segala kegiatan yang berupa proses pengelolaan usaha kerjasama sekelompok manusia yang tergolong dalam organisasi pendidikan, untuk mencapai tujuan pendidikan yang telah ditetapkan sebelumnya, agar efektif dan efisien.

Manajemen peserta didik termasuk salah satu bagian dari manajemen sekolah yang menduduki tempat sangat penting karena sentral layanan pendidikan di sekolah ada pada peserta didik. Kegiatan kesiswaan menitik beratkan pada pelayanan siswa secara individual dengan harapan agar para siswa dapat berkembang sesuai dengan bakat, kemampuan dan perbedaan individu masing-masing. Manajemen peserta didik sebagai usaha pengaturan terhadap peserta didik tersebut masuk sekolah sampai mereka lulus sekolah ${ }^{2}$.

Manajemen kesiswaan merupakan kegiatan pencatatan siswa dari proses penerimaan hingga siswa tersebut keluar dari sekolah disebabkan telah tamat. Hal ini senada dengan pendapat yang menyebutkan bahwa manajemen kesiswaan adalah kegiatan pencatatan siswa mulai dari proses penerimaan hingga siswa tersebut lulus dari sekolah disebabkan karena tamat atau sebab lain ${ }^{3}$.

Sumber daya manusia merupakan komponen paling berharga dalam suatu organisasi karena mereka merupakan energi dan sumber kemajuan dalam mengembangkan organisasi termasuk madrasah. Hal ini menjelaskan bahwa dengan adanya proses rekrutmen, penempatan, pelatihan dan pengembangan

\footnotetext{
${ }^{1}$ Usman, Husaini. Manajemen : Teori, Praktik, dan Riset Pendidikan Edisi Jakarta: Bumi Aksara. Hal.

${ }^{2}$ Imron, Ali, Maysaroh, dan Burhanuddin.. Manajemen Pendidikan ; Analisis Substantif dan Aplikasinya dalam Institusi Pendidikan. Tim Pakar Pendidikan Universitas Negeri Malang. Malang : Universitas Negeri Malang. 2003. Hal.

${ }^{3}$ Arikunto, Suharsimi. 2010. Prosedur Penelitian : Suatu Pendekatan Praktik. Jakarta: Rineka Cipta.

2010 Hal. 4.
} 
anggota dalam sebuah organisasi, maka organisasi tersebut akan mendapati orang-orang terbaik dan kompeten yang dapat membantu organisasi dalam memenuhi tujuan secara efektif dan efisien. Manajemen sumber daya manusia meliputi penempatan personel dalam struktur, job description (pembagian tugas), jalur intruksi dan koordinasi, pola interaksi serta komunikasi, mekanisme kenaikan karir, pengembangan kompetensi, dan lain-lain ${ }^{4}$.

Budaya organisasi adalah pola pemecahan masalah eksternal dan internal yang diterapkan secara konsisten bagi suatu kelompok, dan oleh karenanya diajarkan kepada anggota-anggota baru sebagai cara yang benar dalam memandang, memikirkan dan merasakan masalah yang dihadapi tersebut". "Organizational culture is a common perception held by the

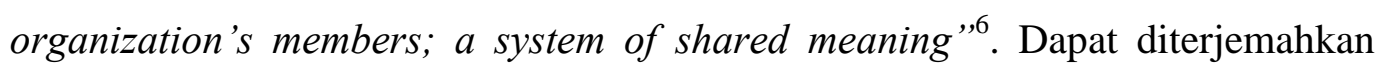
"budaya organisasi adalah suatu persepsi bersama yang dianut oleh anggotaanggota organisasi itu; suatu sistem dari makna bersama". Artinya bahwa budaya organisasi terwujud dalam filosofi, ideologi, nilai-nilai, asumsi, keyakinan serta sikap dan norma bersama anggota-anggota organisasi tersebut dalam memandang berbagai realitas, terutama berkaitan dengan permasalahan internal maupun eksternal.

Pelaksanaan kurikulum mencakup isu: (1) kualitas program yang diberikan, (2) keterlibatan guru dalam pembelajaran, (3) harapan masyarakat sekolah, (4) teknik motivasi untuk memenuhi harapan ini, (5) alokasi waktu, (6) tipe pembelajaran, (7) pemantauan kemajuan belajar, (8) tingkat keterlibatan peserta didik dalam pembelajaran, dan (9) fasilitas belajar yang disediakan sekolah $^{7}$.

\footnotetext{
${ }^{4}$ Asmani, Jamal Ma'mur. Kiat Melahirkan Madrasah Unggulan. Jogjakarta:Diva Pres. 2013. Hal. 160,

${ }^{5}$ Bungin, Burhan. Metode Penelitian Kualitatif: Aktualisasi Metodologis ke Arah Ragam Varian Kontemporer. Jakarta : Rajawali Press.2004. Hal. 100.

${ }^{6}$ Robbins, S.P. Perilaku Organisasi. Jakarta: PT Indeks Kelompok Gramedia edisi 9. Stoner, J.A.F dan $1991 \mathrm{Hal} 572$.

${ }^{7}$ Mulyasa, HE. Manajemen dan Kepemimpinan Kepala Sekolah. Bandung: Bumi Aksara. 2012. Hal. 75.
} 


\section{METODE PENELITIAN}

Penelitian ini bertujuan mendapatkan gambaran mendalam tentang manajemen pengembangan Madarasah Aliyah Darusshalihin NW Kalijaga dengan menggunakan pendekatan penelitian kualitatif dengan teori fenomenologi. fenomenologi pada dasarnya berpandangan bahwa apa yang tampak di permukaan, termasuk pola perilaku sehari-hari hanyalah suatu gejala atau fenomena dari apa yang tersembunyi di "kepala" sang pelaku. Perilaku apapun yang tampak di tingkat permukaan baru bisa dipahami manakala bisa mengungkap atau membongkar apa yang tersembunyi dalam dunia pengetahuan si pelaku. Peneliti dalam pandangan fenomologis berusaha memahami arti peristiwa dan kaitan-kaitannya terhadap orang-orang yang berada dalam situasisituasi tertentu.

Peneliti menggunakan teori fenomenologis dalam penelitian ini untuk dapat mengungkap fenomena-fenomena yang ada mengenai manajemen pengembangan MA Darushalihin NW Kalijaga dan peneliti akan berupaya menemukan peristiwa-peristiwa yang dapat dipahami peneliti dan berbagai pendapat informan. Penelitian ini juga diharapkan dapat mendeskripsikan data secara menyeluruh dan utuh mengenai manajemen pendidikan agama islam di MA Darushalihin NW Kalijaga.

Peneliti memilih rancangan studi kasus karena peneliti ingin menjawab pertanyaan bagaimana manajemen pengembangan madrasah di MA Darushalihin NW Kalijaga sehingga menjadi salah satu sekolah favorit di Kalijaga menarik minat masyarakat untuk menyekolahkan anak mereka di madrasah dengan melakukan eksplorasi secara mendalam terhadap program, kejadian, proses dan aktivitas yang ada di madrasah. dengan manajemen pengembangan madrasah di MA Darushalihin NW Kalijaga.

Penentuan informan dalam penelitian ini dilakukan dengan teknik purposive sampling. Pengambilan sampel bukan dimaksudkan untuk mewakili populasi, melainkan pada relevansi dan kedalaman informasi serta didasarkan pada tema yang muncul dilapangan. Melalui teknik ini dapat dikembangkan 
untuk memperoleh informan lainnya dengan teknik sampel bola salju (snowball sampling) sampai dirasakan data yang diperoleh sudah sangat baik/jenuh.

Pengumpulan data dalam penelitian ini dapat dilakukan dalam berbagai setting, berbagai sumber dan berbagai cara. Teknik pengumpulan data yang dilakukan dengan observasi, wawancara, dokumentasi dan gabungan ketiganya. Penelitian ini menggunakan ketiga teknik tersebut, akan tetapi yang lebih utama adalah teknik wawancara mendalam karena teknik ini dapat mengungkapkan makna yang tersembunyi dibalik suatu fenomena yang nampak. Sedangkan teknik pengumpulan data dengan observasi dan dokumentasi digunakan untuk membantu, memperkaya, dan melengkapi data penelitian.

Peneliti sudah terlibat sepenuhnya terhadap apa yang dilakukan sumber data dengan mengamati langsung apa yang dikerjakan orang, mendengarkan apa yang mereka ucapkan, dan berpartisipasi dalam aktivitas mereka. Peneliti akan mengadakan pengamatan langsung terhadap objek penelitian berupa kegiatan pelaksanaan manajemen pengembangan MA Darushalihin NW Kalijaga.

Analisa data dalam penelitian kualitatif bersifat induktif dan berkelanjutan. Analisis data kualitatif adalah proses mencari serta menyusun secara sistematis data yang diperoleh dari hasil wawancara, catatan lapangan, dan bahan-bahan lainnya sehingga mudah dipahami dan diinformasikan kepada orang lain.

Sementara Proses analisis data diawali dengan menelaah sejumlah data yang ada yang berasal dari berbagai sumber seperti: wawancara, pengamatan, dokumentasi, dan sebagainya. Kemudian melakukan reduksi data yang dilakukan dengan membuat abstraksi yakni membuat rangkuman, kemudian menyusunnya dalam satuan sambil membuat koding atau pengolahan.

Pengecekan keabsahan data merupakan bagian yang penting dalam penelitian kualitatif untuk mengetahui dan mengecek kebenaran data yang diperoleh. Untuk melihat tingkat kepercayaan hasil penelitian dapat digunakan beberapa cara yaitu dengan kredibilitas, transferabilitas dan konfirmabilitas.

Namun yang utama adalah uji kredibilitas data yakni dengan melakukan perpanjangan pengamatan, meningkatkan ketekunan, triangulasi, diskusi dengan 
teman sejawat, member check dan analisis kasus negatif. Triangulasi adalah teknik pemeriksaan keabsahan data yang memanfaatkan sesuatu yang lain di luar data itu untuk keperluan pengecekan atau sebagai pembanding terhadap data itu. Pengujian terhadap kredibilitas data dalam penelitian ini dilakukan dengan triangulasi sumber data dan pemanfaatan metode, serta member check. Triangulasi sumber data dilakukan dengan cara menanyakan kebenaran suatu data atau informasi yang diperoleh dari seorang informan kepada informan lainnya. Misalnya dari guru yang satu ke guru yang lainnya, dari kepala madrasah ke wakil kepala madrasah dan sebagainya.

\section{HASIL DAN PEMBAHASAN}

Manajemen ditinjau dari konsep Islam dipandang sebagai perwujudan amal sholeh yang harus bertitik tolak dari niat baik. Niat baik tersebut akan memunculkan motivasi aktivitas untuk mencapai hasil yang bagus demi kesejahteraan bersama. Manajemen madrasah meliputi perencanaan program madrasah, pelaksanaan rencana kerja madrasah, pengawasan dan evaluasi.

Madrasah unggulan mengandung pengertian lebih tinggi, lebih pandai, lebih cakap dan melebihi dari yang lain. Dengan kata unggul diharapkan setiap siswa memiliki nilai lebih dari yang lain. Baik dalam perolehan NEM yang tinggi, unggul dalam kedisiplinan, unggul dalam kegiatan-kegiatan kesenian, olahraga, karya ilmiah dan lainnya.

Tenaga pendidik dan tenaga kependidikan juga profesional dalam melaksanakan tugasnya.

\section{a. Pengawasan dan Evaluasi}

Kepala madrasah melakukan pengawasan dan evaluasi untuk mengetahui sejauh mana efektifitas program yang sedang dan sudah berjalan. Kepala madrasah menyusun program pengawasan didasarkan pada Standar Nasional Pendidikan.

Dalam penyusunan progam pengawasan, kepala madrasah di bantu oleh wakil kepala bidang kurikulum, terutama berkaitan dengan jadwal supervisi akademik. Jadwal tersebut di letakkan di ruang guru agar mereka tahu kapan 
waktu mereka di supervisi. Setelah kepala madrasah melakukan pengawasan, langkah selanjutnya adalah mengadakan evaluasi.

Evaluasi bertujuan untuk menilai apakah program yang sudah dijalankan berhasil atau tidak. Evaluasi guru berkaitan dengan hasil setelah proses pembelajaran berakhir. Dalam kegiatan evaluasi, madrasah juga membuat EDS setiap tahun untuk mengetahui kelemahan-kelemahan, dan meningkatkannya pada tahun berikutnya. Selain EDS, program akreditasi juga merupakan evaluasi terhadap pelaksanaan 8 SNP di madrasah.

\section{b. Sistem Informasi Manajemen di MA Darusshalihin NW Kalijaga}

Pengembangan implementasi teknologi informasi dan komunikasi di madrasah merupakan upaya yang sudah seharusnya dilakukan untuk menghapus image negatif masyarakat yang menggangap madrasah sebagai lembaga pendidikan second class, minim fasilitas, tidak maju dan gaptek hilang. Untuk merespon tuntutan masyarakat yang sangat dinamis, MA Darushalihin NW Kalijaga menggunakan Sistem Informasi Manajemen (SIM) dalam mengelola kegiatan- kegiatannya secara profesional baik dalam bidang manajemen kesiswaan, kurikulum, keuangan, sarana prasarana dan lain-lain. Hasil observasi yang diperoleh peneliti adalah bahwa dalam segala kegiatan manajemen terutama yang berkaitan dengan administrasi guru, staf maupun siswa sudah terkomputerisasi dengan baik.

Adanya WIFI memudahkan warga madrasah untuk mencari informasi melalui internet. Sistem Informasi Manajemen sangat berguna dalam membantu proses perencanaan, pengelolaan dan pengevaluasian administrasi sekolah dan akademik sekolah. Dengan adanya Sistem Informasi tersebut, maka akan mendukung kinerja madrasah dengan meningkatkan efisiensi, efektivitas dan produktivitas layanan bagi masyarakat baik eksternal maupun internal. Penggunaan teknologi yang efektif untuk pembelajaran akan meningkatkan kreativitas siswa-siswi dan guru. 


\section{Budaya Madrasah MA Darusshalihin NW Kalijaga}

Budaya madrasah dinyatakan sebagai suatu kebiasaan dan nilai-nilai positif yang diterapkan di madrasah yang dibangun dari hasil pertemuan antara nilai- nilai yang dianut oleh kepala madrasah sebagai pemimpin dengan nilai-nilai yang dianut oleh guru, para karyawan, dan siswa yang ada di madrasah tersebut. Budaya yang kuat membutuhkan kemampuan kepala madrasah dalam memberikan pemaknaan terhadap visi tentang mutu madrasah.

Budaya madrasah dikelola dan dibentuk menjadi aktivitas rutin dalam manajemen organisasi, terutama dilakukan terhadap simbol-simbol, normanorma, nilai-nilai dan perilaku dalam organisasi.

Ada beberapa cara membentuk budaya yaitu melalui partisipasi dan komitmen, tindakan simbolik, hadiah dan pengakuan dan membangun kontrol sosial : (1) membentuk budaya melalui partisipasi dan komitmen; (2) Membentuk budaya melalui tindakan-tindakan simbolik; (3) Membentuk budaya melalui hadiah dan pengakuan

Guru memiliki andil yang sangat besar terhadap keberhasilan pembelajaran di sekolah. Minat, bakat, kemampuan dan potensi॰potensi yang dimiliki oleh peserta didik tidak akan berkembang secara optimal tanpa bantuan guru. Di kegiatan belajar mengajar kelas unggulan guru dituntut mempunyai wawasan yang luas serta mampu menjadi fasilitator yang bertugas memberikan kemudahan belajar (facilitate of learning) kepada seluruh peserta didik agar dapat belajar dalam suasana yang menyenangkan, gembira, penuh semangat, tidak cemas, dan berani mengemukakan pendapat secara terbuka. Guru harus kreatif dalam merancang bahan pembelajaran, sumber ajar dan menggunakan media yang menarik Kurikulum dan pembelajaran merupakan dua komponen yang tidak dapat dipisahkan dan bagian dari manajemen madrasah yang sangat penting.

Pelaksanaan kurikulum tingkat kelas ditugaskan langsung kepada para guru. Pembagian tugas ini meliputi kegiatan dalam bidang proses belajar mengajar, pembinaan kegiatan ekstrakulikuler dan kegiatan bimbingan belajar. Dalam pelaksanaan pembelajaran di kelas yang harus diperhatikan oleh guru 
adalah bagaimana karakteristik siswa, kesiapan siswa belajar, dan kemampuan siswa dalam menangkap informasi. Guru juga harus menunjukkan perilaku yang baik kepada siswa seperti santun dalam berbicara dan mendisiplinkan dirinya terlebih dahulu agar kedisiplinan siswa tercapai. kurikulum MA Darusshalihin NW Kalijaga didasarkan atas muatan Kurikulum 2013, dimana muatan mata pelajaran agama lebih banyak.

Kurikulum madrasah juga dibedakan untuk kelas regular dan kelas unggulan dengan beberapa penambahan jam pada mata pelajaran tertentu sebagai bekal mereka di masyarakat. Madrasah mengembangkan muatan lokal sebagai karakteristik daerah. Sementara muatan lifeskill belum sepenuhnya dikembangkan.

Evaluasi atau penilaian menjadi hal yang penting dalam proses belajar mengajar, karena dengan adanya evaluasi kita dapat mengukur sejauhmana tujuan pembelajaran yang kita inginkan sudah tercapai.

\section{Pengembangan Sumber Daya Manusia di MA Darusshalihin NW Kalijaga}

Dalam melakukan analisis kebutuhan pengembangan SDM ini, kepala madrasah meminta masukan atau data dari Kepala Tata Usaha dan wakil kepala bidang kurikulum untuk menentukan guru dan staf yang akan mengikuti pelatihan. Biasanya waka kurikulum akan mengusulkan guru yang belum pernah mengikuti pelatihan atau guru yang dari hasil pemetaan dianggap perlu untuk diikut sertakan dalam pelatihan. Pegawai staf tata usaha yang belum terampil dalam menggunakan teknologi informasi juga diutamakan untuk mengikuti program pelatihan.

Madrasah telah menentukan pengembangan guru dan staf yang tepat bagi kebutuhan mereka. Pengembangan guru dan staf di MA Darushalihin NW Kalijaga melalui pendidikan, kegiatan pelatihan, lokakarya, dan MGMP. Guru dapat mengembangkan karirnya melalui pendidikan, promosi dan penghargaan diberikan bagi guru dan staf yang dianggap cakap oleh kepala madrasah, dan ada juga yang melalui mutasi. 


\section{Pengelolaan saran dan Prasarana Pendidikan di MA Darusshalihin NW Kalijaga}

Semua sarana prasarana madrasah dan sarana belajar selalu dalam kondisi siap pakai pada setiap saat diperlukan. Perlengkapan di madrasah tidak hanya ditata dengan rapi tetapi juga harus dipelihara dengan sebaik-baiknya. Dengan pemeliharaan secara teratur semua sarana dan prasarana pendidikan di madrasah selalu enak dipandang, mudah digunakan, dan tidak cepat rusak. Pemeliharaan sarana dan prarana menjadi tanggung jawab semua warga madrasah. Kepala Madrasah menunjuk salah seorang staf tata usaha dan wakil kepala bidang sarana prasarana yang bertanggung jawab dalam pengadministrasian dan pemeliharaan sarana prasarana madrasah. Penataan dan pemeliharaan sarana prasarana dapat dilakukan dengan memberi label dan kode-kode pada sarana tertentu seperti meja, kursi, dan lemari yang ada di ruang kelas, dan diperiksa secara berkala oleh waka sarana.

Karena itu pengelolaan sarana prasarana pendidikan di MA Darusshalihin NW Kalijaga di mulai dari perencanaan kebutuhan sarana prasarana yang dibutuhkan sesuai dengan skala prioritas dan dana yang tersedia. Sarana prasarana pendidikan di madrasah sudah cukup lengkap walaupun belum sepenuhnya memenuhi Standar Pelayanan Minimal (SPM). Pemeliharaan sarana prasarana menjadi tanggung jawab seluruh warga madrasah.

\section{PEMBAHASAN HASIL PENELITIAN}

Pembahasan hasil penelitian ini meliputi manajemen madrasah, budaya madrasah, penerimaan peserta didik baru, kurikulum madrasah, pengembangan sumber daya manusia, dan pengelolaan sarana prasarana pendidikan.

\section{Manajemen madrasah di MA Darusshalihin NW Kalijaga}

Manajemen madrasah di MA Darusshalihin NW Kalijaga dilaksanakan berdasarkan Peraturan Pemerintah RI No.19 tentang Standar Pengelolaan Madrasah tahun 2007 yang mengatur tentang perencanaan program madrasah, pelaksanaan rencana kerja, kepemimpinan kepala madrasah, pengawasan dan evaluasi, serta ditambah dengan sistem informasi manajemen madrasah. 
Eksistensi dan prestasi sebuah lembaga pendidikan ditentukan oleh kemampuan kepala madrasah dalam menyusun perencanaan madrasah baik jangka pendek, menengah maupun panjang. Perencanaan diperlukan untuk menentukan tujuan-tujuan yang hendak dicapai pada masa yang akan datang dan apa yang harus diperbuat agar dapat mencapai tujuan-tujuan itu. Berdasarkan hasil temuan data penelitian, Kepala MA Darusshalihin NW kalijaga sudah menyusun perencanaan program madrasah yang komprehensif untuk mengoptimalkan pemanfaatan sumber daya yang ada dan yang mungkin diperoleh guna mencapai tujuan yang diinginkan di masa mendatang bersama stakeholder, wakil kepala, guru dan kepala tata usaha ${ }^{8}$.

Madrasah memiliki visi menjadi madrasah unggulan yang kompetitif dan berakhlakul karimah. Visi tersebut dijabarkan kedalam misi dan tujuan pendidikan yang relevan dengan kebutuhan masyarakat. Sementara mengenai pengawasan dan evaluasi. Pengawasan merupakan kegiatan untuk mengukur pelaksanaan tujuan, menentukan sebab-sebab penyimpangan-penyimpangan dan mengambil tindakan- tindakan korektif bila diperlukan ${ }^{9}$. Dari hasil temuan data penelitian diketahui bahwa kepala madrasah memiliki jadwal supervisi akademik, dan mengevaluasi program yang sudah dijalankan melalui Evaluasi Diri Madrasah (EDM) dan Akreditasi

Hasil supervise akademik, Kepala madrasah dapat mengetahui kelemahan dan kelebihan guru dalam pembelajaran dan dapat memberikan umpan balik setelah pengawasan selesai. Madrasah membuat EDM setahun 1 kali untuk mengetahui kekuatan, kelemahan, peluang dan tantangan madrasah dalam 8 SNP.

MA Darusshalihin NW kalijaga menggunakan Sistem Informasi Manajemen (SIM) dalam mengelola kegiatan-kegiatannya secara profesional baik

\footnotetext{
${ }^{8}$ Terry, GR.,\& Leslie W.Rue (Alih Bahasa). Dasar-Dasar Manajemen. Jakarta: Bumi Aksara. 2013. Hal. 43.

${ }^{9}$ Terry, GR.,\& Leslie W.Rue (Alih Bahasa). Dasar-Dasar Manajemen. Jakarta: Bumi Aksara. 2013. Hal. 9.
} 
dalam bidang manajemen kesiswaan, kurikulum, keuangan, sarana prasarana dan lain-lain.

Semua database guru, staf dan siswa sudah terkomputerisasi, pelayanan gaji lewat ATM, absensi kehadiran guru sudah menggunakan fingerprint, pemasangan WIFI yang memudahkan guru untuk mengakses informasi secara online melalui internet. Untuk MA Darusshalihin NW kalijaga madrasah lebih unggul dalam hal pengadministrasian di banding sekolah umum lainnya.

\section{Budaya Madrasah di MA Darusshalihin NW kalijaga}

Madrasah adalah sekolah umum yang bercirikan Agama Islam sehingga budaya yang diterapkan di madrasah tidak menyimpang dari ajaran Agama Islam dan menitik beratkan pada akhlakul karimah. Budaya sekolah sebagai sekumpulan nilai yang melandasi perilaku, tradisi, kebiasaan keseharian, dan simbol- simbol yang dipraktikkan oleh kepala sekolah, guru, petugas administrasi, siswa, dan masyarakat sekitar sekolah. Budaya sekolah merupakan ciri khas, karakter atau watak, dan citra sekolah tersebut di masyarakat luas ${ }^{10}$.

Berdasarkan hasil penelitian, budaya madrasah yang ada di MA Darusshalihin NW kalijaga adalah kebiasaan-kebiasaan dan nilai-nilai positif yang memberikan keunikan pada madrasah, juga norma- norma yang meliputi peraturan dan perilaku yang berlaku yang disepakati seluruh warga madrasah. Kepala madrasah memiliki peran kunci dalam mengembangkan budaya madrasah yang positif dengan memberikan teladan dan mampu membangun teamwork yang kuat untuk terus mengembangkan kebiasaan- kebiasaan dan nilainilai yang baik di madrasah.

Nilai-nilai adalah suatu gagasan masyarakat tentang apa yang benar atau yang salah ${ }^{11}$. Sementara nilai-nilai penting untuk mempelajari perilaku organisasi,

\footnotetext{
${ }^{10}$ Barnawi, dan Muhamad Arifin. Branded School: Membangun Sekolah Unggul Berbasis Peningkatan Mutu. Jakarta: Ar-Ruzz Media. 2013. Hal.109.

11 Rivai, Veithzal \& Deddy Mulyadi. Kepemimpinan dan Perilaku Organisasi. Jakarta: Rajawali Pers. . 2012 Hal. 257
} 
karena nilai-nilai meletakkan fondasi untuk memahami sikap dan motivasi serta mempengaruhi persepsi orang-orang di organisasi ${ }^{12}$.

Berdasarkan hasil penelitian, MA Darusshalihin NW kalijaga memiliki nilai keunggulan seperti, nilai ibadah, nilai prestise (kebanggaan), nilai kedisiplinan, nilai prestasi dan persaingan, dan nilai keefektifan. Nilai-nilai ini berhubungan dengan pembentukan karakter di sekolah baik dalam kegiatan proses pembelajaran di kelas, budaya madrasah, kegiatan ekstrakurikuler, maupun kegiatan keseharian anak di rumah dan di masyarakat.

Norma selalu berjalan seiring dengan nilai, jika nilai adalah sebuah penghargaan terhadap sesuatu maka norma adalah aturan-aturan yang mengatur tingkah laku manusia dalam bermasyarakat. Dari norma tersebut kita bisa menilai apakah yang di lakukan oleh seseorang itu suatu hal yang baik atau tidak.

Berdasarkan hasil penelitian, MA Darusshalihin NW kalijaga memiliki norma atau aturan-aturan yang harus di patuhi oleh seluruh warga madrasah baik yang tertulis maupun tidak tertulis meliputi norma agama, susila, dan norma hukum. Norma agama terlihat dalam aktivitas keseharian guru dan siswa, aktivitas kegiatan sholat dhuha dan sholat zhuhur berjamaah rutin dilaksanakan oleh seluruh warga madrasah.

Empat cara untuk membentuk dan mengelola budaya organisasi, yaitu melalui pembentukan komitmen, penggunaan symbol, menciptakan imbalan (reward and recognition), dan melalui kontrol sosial ${ }^{13}$. Pembentukan budaya di MA Darusshalihin NW kalijaga telah melalui :

a. Partisipasi dan komitmen.

Komitmen untuk menjadi madrasah unggul sudah di sosialisasikan dengan baik kepada seluruh warga madrasah, sehingga guru dan siswa berkomitmen

${ }^{12}$ Robbins, S.P. Perilaku Organisasi. Jakarta: PT Indeks Kelompok Gramedia edisi 9. 1991. Hal. 309

${ }^{13}$ Kusdi. Budaya Organisasi: Teori, Penelitian, dan Praktik. Jakarta : Salemba Empat. Moleong, Lexy. 2013. Metode Penelitian Kualitatif. Bandung: PT. Remaja Rosdakarya. Mulyasa, HE. 2012. Manajemen dan Kepemimpinan Kepala Sekolah. Bandung: Bumi Aksara. 2010. Hal. 123. 
melaksanakan kebiasaan-kebiasaan, norma-norma maupun nilai-nilai yang telah disepakati bersama. Tanpa adanya partisipasi dan komitmen seluruh warga madrasah, nilai-nilai dan norma-norma yang diharapkan dapat menjadi prilaku organisasi tidak akan terwujud.

Kepala madrasah berupaya menanamkan kebiasaan dan nilai-nilai positif melalui pemberian nilai-nilai ketauladanan dengan menjaga hubungan yang baik diantara kepala sekolah dan guru, guru dan guru, guru dan siswa, siswa dan siswa, serta antar semua warga sekolah.

b. Membentuk budaya melalui tindakan- tindakan simbolik

Kementerian Agama memiliki simbol ikhlas beramal. Seluruh guru dan staf MA Darusshalihin NW kalijaga telah menjadikan simbol tersebut sebagai perilaku sehari-hari dalam berpeilaku, siswa dibiasakan untuk berinfak.

c. Membentuk budaya melalui hadiah dan pengakuan

Kepala madrasah telah membangun sistem penghargaan yang sesuai dengan norma dan nilai yang ada. Peran dan tugas kepala madrasah untuk menciptakan sistem reward yang proporsional dan profesional sangat mendukung lahirnya budaya madrasah yang sehat. Reward atau penghargaan yang diberikan kepala madrasah dapat menjadi motivasi bagi guru dan staf untuk meningkatkan unjuk kerja.

\section{Penerimaan Peserta Didik Baru di MA Darusshalihin NW Kalijaga}

Faktor penentu keberhasilan salah satu program pendidikan di madrasah saat ini adalah proses Penerimaan Peserta Didik Baru (PPDB).

Prosedur penerimaan peserta didik baru dimulai dari pembentukan panitia penerimaan peserta didik baru, rapat penentuan peserta didik baru, pembuatan, pemasangan atau pengiriman pengumuman, pendaftaran peserta didik baru, penentuan peserta didik yang diterima, pengumuman peserta didik yang diterima, dan registrasi peserta didik yang diterima ${ }^{14}$.

\footnotetext{
14 Imron, Ali, Maysaroh, dan Burhanuddin. Manajemen Pendidikan ; Analisis Substantif dan Aplikasinya dalam Institusi Pendidikan. Tim Pakar Pendidikan Universitas Negeri Malang. Malang : Universitas Negeri Malang. 2003. Hal. 57
} 
Berdasarkan hasil penelitian yang dilakukan peneliti, MA Darusshalihin NW kalijaga sudah melaksanakan prosedur penerimaan peserta didik baru sesuai dengan teori tersebut. Yang berbeda adalah bahwa madrasah membedakan syarat pendaftaran antara siswa kelas regular dan siswa kelas unggulan.

Sistem PPDB di MA Darusshalihin NW Kalijaga adalah melalui rekrutmen dan seleksi. Rekrutmen peserta didik adalah sebuah proses pencarian dan pengikatan calon peserta didik yang mampu mendaftar sebagai peserta didik disuatu lembaga pendidikan, dengan pertimbangan syarat-syarat tertentu, yang menjadi standar dari suatu lembaga pendidikan ${ }^{15}$.

Berdasarkan pendapat tersebut, peneliti menyimpulkan bahwa rekrutmen siswa baru adalah proses penerimaan memasuki sebuah sekolah dan merupakan kegiatan untuk mendpatkan sejumlah siswa baru dari berbagai sekolah sesuai dengan jumlah siswa baru yang akan diterima melalui proses seleksi. Tujuan rekrutmen adalah menerima pelamar sebanyak-banyaknya dari berbagai sekolah yang ada, sehingga memungkinkan akan terjaring calon siswa dengan kualitas tertinggi dari yang terbaik. MA Darusshalihin NW Kalijaga melaksanakan proses rekrutmen dan seleksi penerimaan siswa sebelum awal ajaran baru di mulai. Rekrutmen siswa baru melalui undangan LCT dan sosialisasi tim PSB ke sekolah- sekolah, dan untuk kelas unggulan sosialisasi dilakukan oleh kakak kelas di dampingi guru.

Seleksi dilihat dari teknis pelaksanaannya dapat dibedakan ke dalam tiga jenis yaitu: 1) Seleksi administratif dilakukan dengan memeriksa kelengkapan data yang ditulis dalam formulir isian beserta keabsahan lampirannya; 2) Seleksi dilakukan dengan tes pengujian, biasanya berbentuk tes tertulis, lisan dan penampilan; 3) psikotes khusus, wawancara langsung atau wawancara orangorang terdekat yang ada di sekitar pelamar ${ }^{16}$.

\footnotetext{
${ }^{15}$ Rasyid, Brian. Rekrutmen Peserta Didik. dalam http://brianrasyid.blogspot.com/ 2009/11/ rekrutmen peserta didik /. Di akses tanggal 10 November 2017.Hal. 3.

${ }^{16}$ Yuniarsih, Tjutju dan Suwatno. Manajemen Sumber Daya Manusia; Teori, Aplikasi dan Isu Penelitian. Bandung : Alfabeta. 2011. Hal. 104
} 
Madrash Aliyah Darusshalihin NW Kalijaga melaksanakan seleksi administratif, tes tertulis, dan wawancara. Sementara untuk kelas unggulan ada tes potensi akademik dan wawancara Bahasa Inggris. Proses seleksi dalam penerimaan siswa di MA Darusshalihin NW kalijaga baru dilakukan setelah kegiatan rekrutmen berakhir. Seleksi administratif, tes tertulis, dan wawancara bagi calon siswa baru dibedakan antara siswa kelas regular dan siswa unggulan. Ada persyaratan khusus bagi siswa kelas unggulan yaitu melampirkan piagam peringkat 1 sampai 5 atau piagam penghargaan di bidang non akademik. Bagi siswa yang akan masuk kelas unggulan, setelah lulus tes tertulis, mereka akan mengikuti tes potensi akademik dan wawancara Bahasa Inggris. Program kelas unggulan merupakan salah satu strategi madrasah untuk meningkatkan mutu madrasah.

Ada tiga macam kriteria penerimaan peserta didik baru yaitu :

1. Kriteria acuan patokan (standar criteria reference), yaitu suatu penerimaan peserta didik yang didasarkan atas patokan-patokan yang telah ditentukan sebelumnya.

2. Kriteria acuan norma (norm criterian reference), yaitu suatu penerimaan calon peserta didik baru yang didasarkan atas keseluruhan prestasi calon peserta didik yang mengikuti seleksi.

3. Kriteria yang didasarkan atas daya tampung sekolah. Dalam hal ini, sekolah terlebih dahulu menentukan berapa jumlah daya tampungnya atau berapa peserta didik baru yang akan diterima. Setelah sekolah menentukan, kemudian merangking siswa dari yang berprestasi tinggi sampai terendah ${ }^{17}$.

\section{Kurikulum Madrasah MA Darusshalihin NW kalijaga}

Kurikulum merupakan salah satu substansi manajemen madrasah yang sangat penting. Dalam pelaksanaannya, kurikulum tidak dapat dipisahkan dengan pembelajaran dimana terjadi upaya pendidik untuk membantu peserta didik melakukan kegiatan belajar ditinjau dari sudut proses dan sudut hasilnya.

\footnotetext{
${ }^{17}$ Imron, Ali, Maysaroh, dan Burhanuddin. Manajemen Pendidikan ; Analisis Substantif dan Aplikasinya dalam Institusi Pendidikan. Tim Pakar Pendidikan Universitas Negeri Malang. Malang : Universitas Negeri Malang. 2003. Hal. 57.
} 
Madrasah adalah sekolah umum yang bercirikan Agama Islam, muatan kurikulum madrasah sama dengan kurikulum SMP hanya saja porsi pada mata pelajaran agama lebih banyak. Kurikulum merupakan segala pengalaman pendidikan yang diberikan oleh kepala sekolah kepada seluruh peserta didiknya baik dilakukan di dalam sekolah maupun di luar sekolah. Pengalaman peserta didik di sekolah dapat diperoleh melalui berbagai kegiatan pembelajaran baik yang dilakukan di dalam kelas maupun di luar kelas ${ }^{18}$. Pelaksanaan kurikulum dibagi menjadi dua: 1) Pelaksanaan kurikulum tingkat sekolah, yang dalam hal ini langsung ditangani oleh kepala sekolah. Kepala sekolah selain bertanggung jawab supaya kurikulum dapat terlaksana di sekolah, juga berkewajiban melakukan kegiatan- kegiatan yakni menyusun kalender akademik yang akan berlangsung disekolah dalam satu tahun, menyusun jadwal pelajaran dalam satu minggu, pengaturan tugas, kewajiban guru, dan lain-lain yang berkaitan tentang usaha untuk pencapaian tujuan kurikulum; 2) Pelaksanaan kurikulum tingkat kelas, yang dalam hal ini dibagi dan ditugaskan langsung kepada para guru. Pembagian tugas ini meliputi; (a) kegiatan dalam bidang proses belajar mengajar, (b) pembinaan kegiatan ekstrakulikuler yang berada diluar ketentuan kurikulum sebagai penunjang tujuan sekolah, (c) kegiatan bimbingan belajar yang bertujuan untuk mengembangkan potensi yang berada dalam diri siswa dan membantu siswa dalam memecahkan masalah ${ }^{19}$.

Berdasarkan hasil penelitian, kurikulum MA Darusshalihin NW kalijaga menggunakan Kurikulum 2013 dimana madrasah diberi kebebasan untuk menentukan kebijakan dalam merancang dan mengelola kurikulum menurut kebutuhan peserta didik dan masyarakat. Undang-Undang Nomor 20 Tahun 2003 tentang Sistem pendidikan Nasional pada Pasal 30 ayat 2 menyebutkan bahwa "Kurikulum pada semua jenjang dan jenis pendidikan dikembangkan dengan prinsip diversifikasi sesuai dengan satuan pendidikan, potensi daerah, dan

\footnotetext{
${ }^{18}$ Sutikno, M. Sobri. Manajemen Pendidikan: Langkah Praktis mewujudkan Lembaga Pendidikan yang Unggul. Lombok: Holistica. 2012 Hal. 71.

${ }^{19}$ Hamalik, Oemar. Manajemen Pengembangan Kurikulum. Bandung; PT Remaja Rosyda Karya. 2006 Hal 119
} 
siswa." Berdasarkan undang-undang di atas, madrasah bertugas dan berwenang untuk mengembangkan kurikulum muatan lokal dan life skill sesuai dengan kebutuhan masyarakat dan lingkungan setempat ${ }^{20}$. Muatan lokal yang dikembangkan madrasah adalah Bahasa Daerah Lombok dan Tahsin Tahfiz. Lifeskill yang dikembangkan adalah Bahasa Arab dan Bahasa Inggris, walupun baru sebatas untuk siswa kelas unggulan. Kendala yang dihadapi adalah terbatasnya sumber daya manusia yang ada di madrasah.

Tahapan manajemen kurikulum di madrasah dilakukan melalui empat tahap yaitu:

\section{Perencanaan.}

Di awal tahun ajaran baru Kepala MA Darusshalihin NW kalijaga eserta komite dan guru menyusun Kurikulum 2013 dimana madrasah diberi kebebasan untuk menentukan kebijakan dalam merancang dan mengelola kurikulum menurut kebutuhan peserta didik dan masyarakat. Gurupun dituntut untuk menyiapkan perangkat pembelajaran seperti silabus dan RPP. Perangkat pembelajaran harus disusun berdasarkan kebutuhan dan mengacu kepada silabus atau kurikulum yang berlaku. Persiapan guru dalam proses belajar mengajar itu penting karena akan berpengaruh terhadap persiapan, proses, dan evaluasi belajar. Guru yang baik adalah guru yang membuat perencanaan. Karena dengan adanya perencanaan maka pelaksanaan pengajaran menjadi baik dan efektif.

2. Pengorganisasian dan koordinasi.

Muatan kurikulum madrasah sama dengan muatan kurikulum MA hanya saja porsi pada mata pelajaran agama lebih banyak. Rumpun mata pelajaran agama dibagi menjadi 5 yaitu; Akidah Akhlak, SKI, Qur'an Hadits, Fikih dan Bahasa Arab. MA Darusshalihin NW kalijaga juga membedakan muatan kurikulum kelas regular dengan kurikulum di kelas unggulan dengan penambahan jam pada mata pelajaran yang diunggulkan seperti Bahasa Inggris, Bahasa Arab dan Matematika.

\section{Pelaksanaan.}

${ }^{20}$ Undang-Undang Nomor 20 Tahun 2003. tentang Sistem pendidikan Nasional 
Untuk menjamin peserta didik belajar maka harus dilakukan proses interaksi antara pendidik dan peserta didik sebagai bentuk pelaksanaan rencana pembelajaran yang telah dibuat. Dalam pelaksanaan proses pembelajaran, guru tidak hanya mengajar di dalam kelas saja, tetapi guru juga melibatkan lingkungan sekolah sebagai sarana belajar. Guru memahami bahwa belajar bagi siswa tidak terjadi secara instan melainkan perlu proses. Kualitas dan keunggulan belajar sangat dipengaruhi oleh kuantitas dan kualitas interaksi dengan informasi dan lingkungannya. Guru dalam kegiatan belajar mengajar di kelas unggulan dituntut mempunyai wawasan yang luas serta persyaratan lainnya yang mampu mengarahkan peserta didik untuk mewujudkan tujuan hidupnya secara optimal, siap beradaptasi, siap menghadapi berbagai kemungkinan dan siap memasuki era globalisasi yang penuh tantangan.

4. Evaluasi

Evaluasi menjadi hal yang penting dalam proses belajar mengajar, karena dengan adanya evaluasi kita dapat mengukur sejauhmana tujuan pembelajaran yang kita inginkan sudah tercapai.

Evaluasi proses pembelajaran merupakan tahap yang perlu dilakukan oleh guru untuk menentukan kualitas pembelajaran. Kegiatan ini sering disebut juga sebagai refleksi proses pembelajaran, karena kita akan menemukan kelebihan dan kekurangan dari proses pembelajaran yang telah dilakukan. Guru tidak hanya mengevaluasi hasil belajar siswa melalui ulangan harian, mid semester maupun semester, tetapi guru juga menilai bagaimana minat, motivasi, keuletan dan sikap siswa dalam pembelajaran. Madrasah memiliki program ekstrakurikuler yang di dalamnya terkandung nilai-nilai karakter, tetapi kegiatan ini belum seluruhnya diikuti oleh seluruh siswa karena terbatasnya SDM yang ada di madrasah. Bimbingan belajar diberikan tidak hanya untuk siswa yang akan mengikuti ujian saja, tetapi juga diberikan kepada siswa yang memiliki bakat khusus pada mata pelajaran tertentu. Bagi siswa yang mengalami kesulitan belajar, guru juga dapat memberikan pelajaran tambahan. 


\section{Pengembangan Sumber Daya manusia di MA Darusshalihin NW Kalijaga}

Keberhasilan pendidikan di madrasah sangat ditentukan oleh keberhasilan kepala madrasah dalam mengelola dan memberdayakan sumber daya manusia yang ada di madrasah termasuk pengembangan guru dan staf. Manajemen sumber manusia adalah fungsi-fungsi manajemen yang berkaitan dengan rekrutmen, penempatan, pelatihan dan pengembangan anggota organisasi. Sementara pelatihan dan pengembangan (training and development) merupakan upaya strategis dalam proses manajemen untuk meningkatkan kompetensi/kualitas sumber daya manusia ${ }^{21}$.

Pengembangan pegawai merupakan aktivitas memelihara dan meningkatkan kompetensi pegawai guna mencapai efektivitas organisasi. Pengembangan pegawai dapat diwujudkan melalui pengembangan karir, serta pendidikan dan pelatihan ${ }^{22}$.

a. Pendidikan dan pelatihan

Pendidikan dan pelatihan merupakan penciptaan suatu lingkungan di mana para pegawai dapat memperoleh atau mempelajari sikap, kemampuan, keahlian, pengetahuan dan prilaku yang spesifik yang berkaitan dengan pekerjaan Pengembangan karir merupakan pendekatan formal yang digunakan organisasi untuk menjamin bahwa pegawai dengan kualifikasi tepat dan berpengalaman tersedia pada saat dibutuhkan. Pengembangan karir terdiri atas (a) Career Planning, yaitu bagaimana pegawai merencanakan dan mewujudkan tujuan-tujuan karirnya sendiri; (b) Career Management, yaitu bagaimana organisasi mendesain dan melaksanakan pengembangan karir pegawai. Pengembangan karir adalah outcome atau hasil yang berasal dari interaksi antara karir individu dengan proses manajemen karir organisasi.

b. Pengembangan karir merupakan pendekatan formal yang digunakan organisasi untuk menjamin bahwa pegawai dengan kualifikasi tepat dan

\footnotetext{
${ }^{21}$ Stoner, J.A.F dan Freemen, R.E. Management. $4^{\text {th }}$ Edition. United States of America : Prentice Hall International (Inc) edition. 1989.hal. 329

${ }^{22}$ Yuniarsih, Tjutju dan Suwatno. Manajemen Sumber Daya Manusia; Teori, Aplikasi dan Isu Penelitian. Bandung : Alfabet. 2011. Hal. 133.
} 
berpengalaman tersedia pada saat dibutuhkan. Pengembangan karir terdiri atas (a) Career Planning, yaitu bagaimana pegawai merencanakan dan mewujudkan tujuan-tujuan karirnya sendiri; (b) Career Management, yaitu bagaimana organisasi mendesain dan melaksanakan pengembangan karir pegawai. Pengembangan karir adalah outcome atau hasil yang berasal dari interaksi antara karir individu dengan proses manajemen karir organisasi.

Hasil penelitian menunjukkan bahwa Kepala MA Darusshalihin NW Kalijaga selalu berupaya untuk meningkatkan mutu pendidikan di madrasah melalui pengembangan guru dan staf dengan beberapa cara yaitu: (1) Melakukan analisis kebutuhan berdasarkan kinerja, analisis persyaratan pekerjaan, dan analisis organisasi. Setelah kebutuhan pelatihan organisasi telah diidentifikasi, madrasah segera memulai upaya pelatihan yang sesuai; (2) Kepala madrasah memberi kesempatan dan motivasi untuk guru yang ingin melanjutkan pendidikan ke jenjang S2 dengan memberi kemudahan dan dukungan untuk peningkatan kompetensi guru. Saat ini, beberpa orang Guru yang sudah dan sedang menyelesaikan pendidikannya ke jenjang Pasca Sarjana yang ada di Universitas mataram dan UIN Mataram; (3) Mengikutsertakan guru dan staf mengikuti kegiatan-kegiatan pelatihan yang sudah diprogramkan seperti workshop, MGMP, dan diklat yang menunjang pengembangan profesi guru.

Kepala madrasah tidak hanya melibatkan guru, tetapi juga memberi kesempatan kepada staf untuk meningkatkan kemampuan mereka dala menguasai IT dan bekerjasama dengan lembaga kursus. Guru yang sudah mendapat sertifikat profesi dituntut untuk selalu meningkatkan kualitas diri mereka melalui berbagai kegiatan pengembangan keprofesian seperti membuat karya ilmiah, karya seni, PTK, jurnal maupun publikasi ilmiah; (4) Pengembangan karir guru dan staf dengan mempromosikan guru dan staf yang dianggap berprestasi dan cakap dalam melaksanakan tugas dengan diberi jabatan dengan beban dan tanggung jawab yang lebih besar daripada jabatan semula, seperti menjadi wakil kepala, pembina bahkan kepala madrasah dan mutasi ke madrasah lain untuk meningkatkan karir guru dan staf, seperti 
mutasi untuk menjadi kepala madrasah, kepala tata usaha, dan pengawas madrasah.

\section{Pengelolaan Sarana Prasarana Pendidikan MA Darusshalihin NW Kalijaga}

Sarana prasarana pendidikan merupakan faktor yang sangat penting dalam meningkatkan efisiensi belajar, membelajarkan. Tersedianya berbagai sarana pokok merupakan elemen penting bagi eksistensi madrasah dalam membangun prestasi.

Bafadal mengidentifikasi beberapa hal mengenai tujuan sarana dan prasarana pendidikan yaitu:

1. Untuk mengupayakan Pengadaan saran prasarana pendidikan melalui sistem perencanaan dan pengadaan secara hati hati dan seksama, sehingga sekolah atau madrasah memiliki sarana dan prasarana yang baik sesuai dengan kebutuhan dana yang efisien.

2. Untuk mengupayakan pemakaian sarana dan prasarana sekolah secara tepat dan efisien.

3. Untuk mengupayakan pemeliharaan sarana dan prasarana pendidikan, sehingga keberadaannya selalu dalam keadaan kondisi siap pakai ketika akan digunakan oleh semua personel sekolah ${ }^{23}$.

Berdasarkan hasil penelitian, peneliti dapat menyimpulkan bahwa :

1. MA Darusshalihin NW Kalijaga yang membuat perencanaan untuk selalu berupaya melengkapi sarana dan prasarana pendidikan yang ada di madrasah baik sarana fisik maupun non fisik dalam meningkatkan efisiensi proses pembelajaran. Perencanaan itu diperhitungkan dengan seksama dan matang agar tidak mubazir dalam pengadaan. Perencanaan kebutuhan sarana prasarana dilakukan dengan melakukan analisis kebutuhan dan membuat skala prioritas dengan memadukan rencana kebutuhan pengadaan sarana prasarana dengan dana yang tersedia.

${ }^{23}$ Bafadal, Ibrahim. Pengelolaan Perlengkapan Pendidikan di Sekolah. Jakarta: Bumi Aksara. 2003 Hal. 87 
2. Pengadaan sarana prasarana pembelajaran di kelas unggulan berbeda dengan kelas regular. Hal ini di sebabkan karena waktu belajar siswa kelas unggulan yang lebih lama, sehingga sekolah berinisiatif untuk membuat mereka merasa nyaman di kelas dengan melengkapi fasilitas belajar mereka seperti: pengelolaan kelas yang tertata baik, hordengnya indah, ada AC, tempat air minum, loker siswa, serta LCD sudah terpasang permanen. Sementara fasilitas di kelas regular baru tersedia kipas angin dan LCD yang digunakan bergantian dengan kelas lain. Sarana prasarana penunjang yang tepat dan lengkap juga dapat meningkatkan hasil belajar siswa. Penggunaan teknologiyang efektif untuk pembelajaran akan meningkatkan kreativitas siswasiswi dan guru dalam memperoleh sumber dan bahan pembelajaran.

3. Standar Sarana Prasarana di MA Darusshalihin NW Kalijaga belum seluruhnya sesuai dengan PP No.19 tahun 2005 tentang standar nasional pendidikan yang berkaitan dengan kriteria minimal pada pengadaan buku di perpustakaan untuk 1 buku 1 siswa, ketersediaan jamban, dan kantin yang belum kondusif. Hal ini disebabkan kurangnya luas lahan, besarnya jumlah siswa dan kurangnya dana.

\section{PENUTUP}

\section{Kesimpulan}

Berdasarkan analisis paparan data dan temuan penelitian dapat disimpulkan hasil penelitian sebagai berikut:

1. Manajemen MA Darusshalihin NW Kalijaga meliputi perencanaan program madrasah, pelaksanaan rencana kerja madrasah, pengawasan dan evaluasi serta Sistem Informasi Manajemen, manajemen madrasah sudah sesuai dengan peraturan Pemerintah RI No 19 tahun 2007 tentang Standar Pengelolaan madrasah. Keunggulan Madrasah adalah bahwa sistem infrmasi Manajemen SIM di MA Darusshalihin NW Kalijaga sudah berjalan dengan kinerja madrasah d engan meningkatkan efisiensi, efektivitas dan produktivitas layanan bagi masyarakat baik eksternal maupun internal. 
2. Budaya madrasah yang diterapkan di MA Darusshalihin NW Kalijaga tidak menyimpang dari ajaran Agama Islam dan menitik beratkan pada akhlakul karimah. Budaya madrasah berkaitan erat dengan nilai-nilai positif, normanorma dan kebiasaan-kebiasaan yang mengikat seluruh warga madrasah. Kepala madrasah memiliki peran kunci dalam mengembangkan budaya madrasah yang positif dengan memberikan teladan dan mampu membangun teamwork yang kuat untuk terus mengembangkan kebiasaan-kebiasaan dan nilai-nilai yang baik di madrasah.

3. Budaya madrasah dibentuk melalui : partisipasi dan komitmen, tindakantindakan simbolik, hadiah dan penghargaan serta kontrol sosial. Budaya madrasah yang didesain secara terstruktur, sistematis, dan tepat sesuai dengan kondisi sosial madrasah memberikan kontribusi yang positif bagi peningkatan kualitas sumber daya manusia dalam menuju madrasah yang berkualitas.

4. Penerimaan Peserta Didik Baru di MA Darusshalihin NW Kalijaga adalah salah satu faktor penentu keberhasilan program pendidikan di madrasah saat ini dan berbeda dengan sekolah umum yang ada di Kecamatan Aikmel. Sistem penerimaan peserta didik baru madrasah melalui rekrutmen dan seleksi siswa baru untuk menjaring siswa kelas reguler dan kelas unggulan. Proses ini dilaksanakan untuk mendapatkan input yang baik yang akan menghasilkan output yang amat baik. Madrasah juga menjaring siswa kelas unggulan melalui LCT antar SD/MI, tes potensi akademik, bakat siswa, dan wawancara bahasa Inggris. Kriteria penerimaan pesertadidik baru dengan melihat daya tampung madrasah dan acuan norma.

5. Madrasa Aliyah MA Darusshalihin NW Kalijaga menggunakan Kurikulum 2013 dimana madrasah diberi kebebasan untuk menentukan kebijakan dalam merancang dan mengelola kurikulum menurut kebutuhan peserta didik dan masyarakat. Kurikulum tidak hanya meliputi bahan pelajaran tetapi meliputi seluruh aktivitas siswa baik di dalam maupun di luar kelas. Hubungan sosial antara guru dan murid, metode mengajar, dan cara mengevaluasi termasuk kurikulum. Pelaksanaan kurikulum meliputi pelaksanaan kurikulum tingkat 
sekolah dan kurikulum tingkat kelas. Pelaksanaan kurikulum tingkat kelas meliputi kegiatan proses pembelajaran, kegiatan ekstrakurikuler dan bimbingan belajar. 100\% guru sudah menyiapkan, perangkat pembelajaran, melaksanakan pembelajaran dan termasuk melakukan evaluasi.

6. Pengembangan sumber daya manusia terutama guru dan staf di MA Darusshalihin NW Kalijaga sudah berjalan dan terlaksana dengan baik guna pembentukan keterampilan profesional dan perbaikan layanan sekolah melalui pendidikan, kegiatan- kegiatan seperti pelatihan, penataran, seminar, workshop, dan MGMP. Di samping itu, pengembangan guru dan staf juga dilakukan kepala madrasah melalui promosi dan mutasi sesuai PP Nomor 9 Tahun 2003 guna pengembangan karir mereka. Saat ini, ada beberapa guru madrasah yang telah dan sedang menyelesaikannya pendidikannya di program pasca sarjana yang ada di Propinsi Mataram. Semua ini menunjukkan kepedulian dan dukungan kepala madrasah terhadap guru untuk meningkatkan profesional mereka yang akan berpengaruh pada mutu pendidikan di madrasah. Salah satu bentuk tantangan yang harus dipertimbangkan kepala madrasah adalah pemberian kompensasi bagi guru dan staf yang menunjukkan penilaian kerja amat baik, cakap dan berprestasi.

7. MA Darusshalihin NW Kalijaga selalu berupaya melengkapi sarana dan prasarana pendidikan yang ada di madrasah baik sarana fisik maupun non fisik dalam meningkatkan efisiensi proses pembelajaran. Prestasi ini membuktikan bahwa peningkatan mutu madrasah berjalan dengan baik melalui fasilitas sarana prasarana yang lengkap.

\section{DAFTAR PUSTAKA}

Arikunto, Suharsimi. 2010. Prosedur Penelitian : Suatu Pendekatan Praktik. Jakarta: Rineka Cipta.

Arikunto, Suharsimi dan Lia Yuliana. 2008. Manajemen Pendidikan. Yogyakarta: Aditya Media.

Asmani, Jamal Ma'mur. 2013. Kiat Melahirkan Madrasah Unggulan. Jogjakarta:Diva Press 
Barnawi, dan Muhamad Arifin. 2013. Branded School: Membangun Sekolah Unggul Berbasis Peningkatan Mutu. Jakarta: Ar-Ruzz Media. Bungin, Burhan. 2004. Metode Penelitian Kualitatif: Aktualisasi Metodologis ke Arah Ragam Varian Kontemporer. Jakarta : Rajawali Press

Deal, Terrence E. \& Peterson, Kent D. 1999. Shaping School Culture: The Hearth of Leadership. San Fransisco: Jossey-Bass.

Hamalik, Oemar. 2006. Manajemen Pengembangan Kurikulum. Bandung; PT Remaja Rosyda Karya.

Bafadal, Ibrahim. 2003. Pengelolaan Perlengkapan Pendidikan di Sekolah. Jakarta: Bumi Aksara

Imron, Ali, Maysaroh, dan Burhanuddin. 2003. Manajemen Pendidikan ; Analisis Substantif dan Aplikasinya dalam Institusi Pendidikan. Tim Pakar Pendidikan Universitas Negeri Malang. Malang : Universitas Negeri Malang.

Kusdi. 2010. Budaya Organisasi: Teori, Penelitian, dan Praktik. Jakarta : Salemba Empat. Moleong, Lexy. 2013. Metode Penelitian Kualitatif. Bandung: PT. Remaja Rosdakarya.

Mulyasa, HE. 2012. Manajemen dan Kepemimpinan Kepala Sekolah. Bandung:

Bumi Aksara

Owens, RG. 1991. Organizational Behaviour in Education. 4th edition. Boston: Allyn and Bacon.

Rasyid, Brian. 2009. Rekrutmen Peserta Didik. Dalam http://brianrasyid.blogspot.com/2009/11/rekrutmenpesertadidik/.

Di akses tanggal 10 November 2017.

Rivai, Veithzal \& Deddy Mulyadi. 2012. Kepemimpinan dan Perilaku Organisasi. Jakarta: Rajawali Pers.

Robbins, S.P. 1991. Perilaku Organisasi. Jakarta: PT Indeks Kelompok Gramedia edisi 9.

Stoner, J.A.F dan Freemen, R.E. 1989. Management. 4th Edition. United States of America :Prentice Hall International (Inc) edition.

Sugiyono. 2012. Metode Penelitian Kombinasi (Mixed Methods). Bandung : Alfabeta.

Sutikno, M. Sobri. 2012. Manajemen Pendidikan: Langkah Praktis mewujudkan Lembaga Pendidikan yang Unggul. Lombok: Holistica

Terry, GR.,\& Leslie W.Rue (Alih Bahasa). 2013. Dasar-Dasar Manajemen. Jakarta: Bumi Aksara.

Usman, Husaini. 2009. Manajemen : Teori, Praktik, dan Riset Pendidikan Edisi Jakarta: Bumi Aksara. 
Undang-Undang Nomor 20 Tahun 2003 tentang Sistem pendidikan Nasional pada Pasal 30

Yuniarsih, Tjutju dan Suwatno, 2011. Manajemen Sumber Daya Manusia; Teori, Aplikasi dan Isu Penelitian. Bandung : Alfabeta 